Pak. j. sci. ind. res. Ser. A: phys. sci. 2021 64A(2) 161-172

\title{
Review
}

\section{Techno-Economic Analysis of Green Construction Regulations Plus Survey for Prototype Implementation in Karachi}

\author{
Muhammad Imran Majid ${ }^{a *}$ and Muhammad Ibrahim Khan ${ }^{b}$ \\ aDepartment of Electrical Engineering, Institute of Business Management, Korangi Creek, Karachi, Pakistan \\ ${ }^{\mathrm{b}}$ College of Engineering \& Sciences, Institute of Business Management, Korangi Creek, Karachi, Pakistan
}

(received June 12, 2019; revised February 25, 2020; accepted February 27, 2020)

\begin{abstract}
Conventional buildings consume large amounts of energy and are the source of greenhouse gas emissions contributing to climate change. The shortage of green buildings in Pakistan have been said to be due to shortage of knowledge of the benefits of essential green building materials and the absence of a regulatory framework. The study is qualitative and quantitative and is divided into two parts. This review paper focuses on awareness in the Pakistan's local construction market concerning green buildings through a survey questionnaire. Data collection procedure consists of 60 questionnaires related to green building construction awareness and priorities within Karachi's construction sector. Also, a focus group and personal interviews conducted with at least 5 professionals working in local construction projects are analyzed. The research questions formed from detailed literature review were analyzed and found that energy conservation, environmental/resource conservation and improving indoor environmental quality are major driving factors for green building development. Similarly, there is a lack of knowledge of green construction methods and regulations and lack of support from the government. This has been found as the major barrier in going towards green construction. We recommend policy directions towards this end and elaborate points of concern to the authorities.
\end{abstract}

Keywords: GB (green building), greenhouse gas, sustainable design, energy efficient building, construction industry, climate change

\section{Introduction}

Environmental impacts are changes in the natural or built environment, resulting directly from an activity led by humans have adverse effects on the air, land, water, fish and other occupants of the ecosystem (Thomas, 2017). The excessive use of energy and improper allocation of resources in the design of present day buildings contribute significantly to serious environmental challenges and issues. Construction of a building includes various aspects such as cooling, heating, ventilation and lighting. This cause depletion of resources and severe damage to the environment (Arif, 2011).

Economic activities lead to greenhouse gas emissions which include energy $25 \%$, agriculture $24 \%$, industry $21 \%$, transport $14 \%$, energy-related activities $10 \%$ and buildings $6 \%$ (Abas, 2017). The water demand up to calculable extent is approximately $55 \%$ for the years

*Author for correspondence;

E-mail: imran.majid@iobm.edul.pk
2000-2050 (OECD, 2012). Cement, in all its forms and types, is an important product that combines with other ingredients in the correct proportion, making it a vital construction material. The demand of concrete which is a cement-based construction material is already high and increasing and perceives no fringes. This will keep on being the case for a long time. Despite the steady upgrades in process efficiency that have been received by the cement industry as of late, Ordinary Portland Cement (OPC) production is still liable for around $6 \%$ of all man-made global carbon emissions. To ensure sustainable, cost-effective but still profitable production of cement, the industry needs to change. Hence, the two most significant challenges confronting the industry are a squeezing need to lessen $\mathrm{CO}_{2}$ emissions and improve energy efficiency (Imbabi and Collette, 2012).

The real estate industry has acknowledged environmental sustainability in its decision-making. In develop-ment, there has been a significant shift towards the production of "more environmentally sustainable buildings". 
$40-48 \%$ of new commercial builds are green, contrasted with just $2 \%$ in 2005 (WEF, 2016).

Moving towards sustainable design increased with the launch of Building Research Establishment's Environmental Assessment Method (BREEAM) in 1990, the first green building rating system in the world. In 2000, the U.S. Green Building Council (USGBC) went with the same pattern and developed and released criteria likewise planned for improving the environmental performance of buildings through its Leadership in Energy and Environmental Design (LEED) rating system for new construction. Since its release, LEED has continued to develop in prominence and to incorporate rating systems for existing buildings and entire neighborhoods (Stephanie, 2019). These worldwide initiatives for Green Building encourage structural designers, civil engineers, contractors and project managers to plot creative solutions providing appropriate comfort for occupants whereas minimizing environmental impacts.

In Pakistan, the green building initiatives and concept of operations and management are in the initial phase as per WRI (World Resources Institute) (WRI, 2007). Also, the local construction market lags far behind because of the absence of adequate knowledge of using green construction concepts for buildings. The lack of proper knowledge and no education and absence of proper initiatives and management are the reasons most of the resources are used excessively. Since resources are scarce, population growth has led to a water crisis. Hence, it is the need of the hour to adopt efficient processes which minimize the energy usage and also adhere to the Building codes of Pakistan-energy provisions 2011.

Literature review. This section has been divided into four main sections i.e. green building and environment, a global perspective, project management behavioural aspects, environmental friendly \& energy-efficient materials and green building rating systems and codes.

The interior condition where an inhabitant abides enormously impacts the all-out human wellbeing and its introduction to endless air toxins because of the measure of time they spend indoor and contamination around (Hoang et al., 2009). It is found that materials used in conventional buildings can produce formaldehyde and other toxic or irritating chemicals that when exposed to ozone produces secondary emissions (Weschler, 2000; Mueller, 1973).
All the life cycle phases of a building are found to have great environmental aspects but operational phase has the greatest percentage of energy consumption in the life cycle of a building (Aashish et al., 2011). Energy conservation, enhancing indoor environmental quality, environmental/resource conservation, and waste reduction are four most imperative practices of a sustainable plan/design and development (Amos and Albert, 2016). According to a worldwide study to determine drivers for actualizing green building practices, twenty-one potential drivers for green building practice execution were found which (Darko, 2017) are: Minimize the life cycle estimate of buildings, Increase water-productivity of buildings, Increase energy-productivity of buildings, Improve occupants' well-being and solace and gratification, Increase overall profitability, Limit the environmental effect of structures, Improve indoor ecological quality, Good company/ image/reputation or marketing strategy, Improve the workplace environment, Thermal comfort, Enhance rental pay and expanded rentable space, Attract premium customers and increased property value, Minimize construction and managing wastes, Preservation of natural resources and nonrenewable fuels, Set standards for future design and development, Limit the usage of construction accessories, Attract quality workers and reduce worker turnover, Fulfillment from making the best decision, Encourage a culture of best practice sharing, Effectiveness in development procedures and the executives practices \& Enhance the performance of the national economy and jobs creation.

Also, around sixty-four drivers were recognized from analyzing forty-two chosen experimental studies (Amos Darko, 2017). The arrangement structure for the green building drivers together with five elementary classes: external drivers, corporate-level drivers, property-level drivers, project-level drivers, and individual-level drivers is shown in the Fig. 1.

Also, it has been revealed that five hindrances influencing geen building selection are: lack of knowledge, education, information, research, awareness and expertise, high cost of green building, lack of government incentives and support, lack of interest and demand and lack of green building codes and regulation which influence green building adoption (Ahn et al., 2013).

It has been anticipated that throughout the next fifteen years building vitality use and associated discharges will keep on growing in China. In this manner it is 
required to advance green building improvement in China on dire premise which needs assessment standards other than specialized help. For the purpose an examination of the following latest assessment standards for green structures has been done (Zhang et al., 2017).

- ESGB China's National Evaluation Standard for Green Building

- CSH Britain's Code for Sustainable Homes

- LEED United States Leadership in Energy and Environmental Design

Essential green building materials. A layer of vegetation can be overlaid onto the roof of a building called green roof (Castleton et al. 2010). Green roof is a laminated system containing a waterproofing film, developing medium and the vegetation covering itself. Green roofs mostly incorporate a root obstruction layer, a drainage layer, and a water system framework. A green roof brings many advantages for a building and its encompassing condition like storm water management (Stovin, 2007; Mentens et al., 2006), enhanced water flow quality (Berndtsson et al., 2009), enhanced outdoor air quality in urban areas (Yang et al., 2008), roof life expansion (Teemusk and Mander, 2009) and reducing the impact of the urban heat island (Doug et al., 2005) and expanded architectural interest and biodiversity (Koehler, 2003).

Also, 48-L electronically polished chambers of chrome steel were utilized to test the reactive impact of ozone using ten essential green building materials (Chi et al., 2009):

- ESGB China's National Evaluation Standard for Green Building

- Perlite-based roof tile

- Not glazed earthenware tile

- Natural wall covering

- Aluminium tinted stopper backdrop

- Bamboo

- Ultraviolet covered bamboo

- Wheat board

- Ultraviolet covered wheat board

- Sunflower board, and

- Ultraviolet covered sunflower board

\begin{tabular}{|c|c|c|c|}
\hline & $\begin{array}{l}\text { External drivers } \\
\text { - Government regulations and policies } \\
\text { - Incentive schemes } \\
\text { - Demand from clients/tenants } \\
\text { - GB rating systems } \\
\text { - Promotion and communication } \\
\text { - Proactive role of materials manufacturers] } \\
\text { - Product and material innovation and/or } \\
\text { certification } \\
\text { - Public perception } \\
\text { - Availability of green suppliers } \\
\text { - Education and training } \\
\text { - Knowledge and awareness, and } \\
\text { information }\end{array}$ & \multirow{2}{*}{\multicolumn{2}{|c|}{$\begin{array}{l}\text { Project-level drivers } \\
\text { - Reduced construction costs } \\
\text { - Integrated design approach } \\
\text { - Better ways to measure and } \\
\text { account for costs } \\
\text { - Decreased construction time } \\
\text { - Meeting contract and developers } \\
\text { requirements } \\
\text { - Performance-based standard and } \\
\text { contracts } \\
\text { - New kinds of partnerships and project } \\
\text { stakeholders } \\
\text { - Increased construction time certainty } \\
\text { - Waste reduction } \\
\text { - Improved project constructability } \\
\text { - Reduced on-site worker health and } \\
\text { safety risks } \\
\text { - Well controlled design and construction } \\
\text { - Improved reusable and recycle building } \\
\text { elements } \\
\text { - Superior performance of green materials } \\
\text { - Structural conditions } \\
\text { - Competent team members }\end{array}$}} \\
\hline $\begin{array}{l}\text { Corporate level drivers } \\
\text { - Corporate image, culture and vision } \\
\text { - Corporate social responsibility } \\
\text { - Marketing benefits } \\
\text { - Competitive advantage } \\
\text { - Improved occupants producitvity } \\
\text { - High return on investment } \\
\text { - Attraction and retention of quality staff } \\
\text { - Company policey }\end{array}$ & \multirow{2}{*}{$\begin{array}{l}\text { Property-level drivers } \\
\text { - Reduced whole life-cycle costs } \\
\text { - Increased property values } \\
\text { - Attract premium clients and high rental } \\
\text { returns } \\
\text { - Reduced liability and risks } \\
\text { - Lower vacancy rates } \\
\text { - Decreased obsolescence } \\
\text { - Energy conservation } \\
\text { - Environmental protection } \\
\text { - Resource conservation } \\
\text { - Ease in resale \& high resale value } \\
\text { - Reduced depreciation in rent \& pricel } \\
\text { - Increased probability of lease renewal } \\
\text { - Decreased tenant rent concessions } \\
\text { - Achieve high quality building } \\
\text { - Increased longevity of building } \\
\text { - Reduced insurance costs }\end{array}$} & & \\
\hline $\begin{array}{l}\text { - Improved indoor environmental quality } \\
\text { - Improved occupants health, wellbeing, } \\
\text { and satisfaction } \\
\text { - Impress regulators } \\
\text { - Reduced payback period } \\
\text { - Creation of better future oportunities } \\
\text { - Helps to transform the market } \\
\text { - Familiarity with green products/processes } \\
\text { - Recognition within the industry }\end{array}$ & & & $\begin{array}{l}\text { Individual-level drivers } \\
\text { - Moral imperative or social } \\
\text { conscience } \\
\text { - Personal commitment } \\
\text { - Attitudes and traditions } \\
\text { - Self-identity }\end{array}$ \\
\hline
\end{tabular}

Fig. 1. Conceptual framework of green building drivers (Amos, 2017). 
ISO 14001 environmental management system. Waste management is a necessary point for any construction company, as every construction project site consumes massive waste (ISO14001, 2015). The detail study also revealed that ISO 14001 EMS (environmental management system) is an internationally agreed standard that sets out the necessities for an environmental management framework. It helps organizations enhance their environmental execution through efficient usage of assets and diminishing of waste, improving partner's confidence (Strahinja, 2019). It likewise helps associations in setting up, overseeing, checking and controlling their ecological issues in an exceedingly "comprehensive" way.

In 1987, ENERCON (national energy conservation center) was established under the Ministry of Environment Pakistan with the aim to create mindfulness among the common people regarding energy efficiency, and for creating policy regarding energy efficient buildings in the country (Sohail and Qureshi, 2011). Up till now, no policy regarding building energy codes has been presented by ENERCON. Having cooperation with PEC (Pakistan Engineering Council), ENERCON has as of late concluded the Building Energy Code of Pakistan Energy Provisions 2011. Here, legal notification is under way for essential changes in the building bylaws. The application of this building energy code can provide up to 30 percent of energy savings in the new structures.

Building expense of water and electricity in terms of with and without providing HVAC cooling system per day. According to Fig. 2 (United Nations, 2017), an average household size around the world is 6 or more in Pakistan. Therefore, we have assumed a minimum of 3 to 6 or even 7 residents per apartment on different floors of the proposed residential cum commercial building. The maximum people in an apartment will be present during timings from $5 \mathrm{pm}$ to $9 \mathrm{am}$.

Table 1. Occupant density (Clevenger and Haymaker, 2006)

\begin{tabular}{lll}
\hline \hline Parameters & Description & Ranges \\
\hline Area/person & Occupant density- & Low: 10 people/1000 \\
& people per area & SF Medium: \\
& based on 10, 24, & 25 people/1000 SF \\
& or 36 students & High: 37.5 people/ \\
& in a 960SF classroom & $1000 \mathrm{SF}$ \\
\hline \hline
\end{tabular}

Figure $3\left(\mathrm{CO}_{2}\right.$ Monitor, 2019) has been used to determine the approximate concentration of $\mathrm{CO}_{2}$ levels indoors on different floors of the building depending upon the number of people present. People are the main reason for carbon dioxide indoors. $\mathrm{CO}_{2}$ emissions will be greater if there are many people present in an area. $\mathrm{CO}_{2}$ is originated because of human respiration. One working person can emit $\mathrm{CO}_{2}$ from $0.08 \mathrm{~m}_{2}$ to $0.38 \mathrm{~m}_{2}$ per hour, depending on the amount of work done.

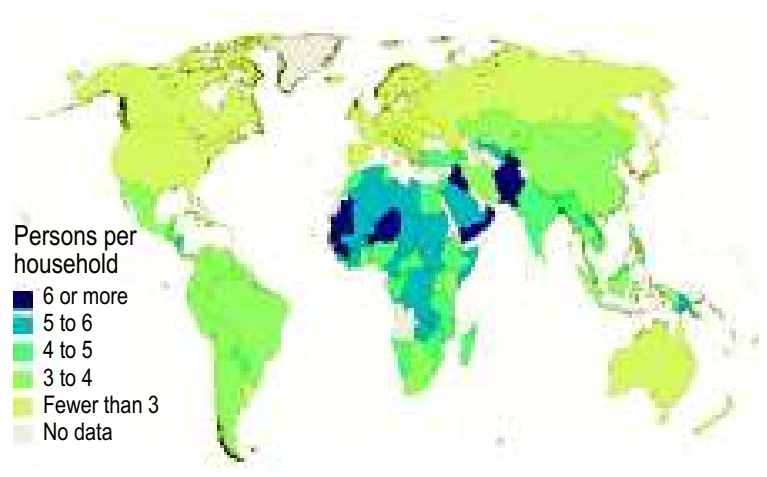

Fig. 2. Average household size around the world, most recent estimate since 2000 .

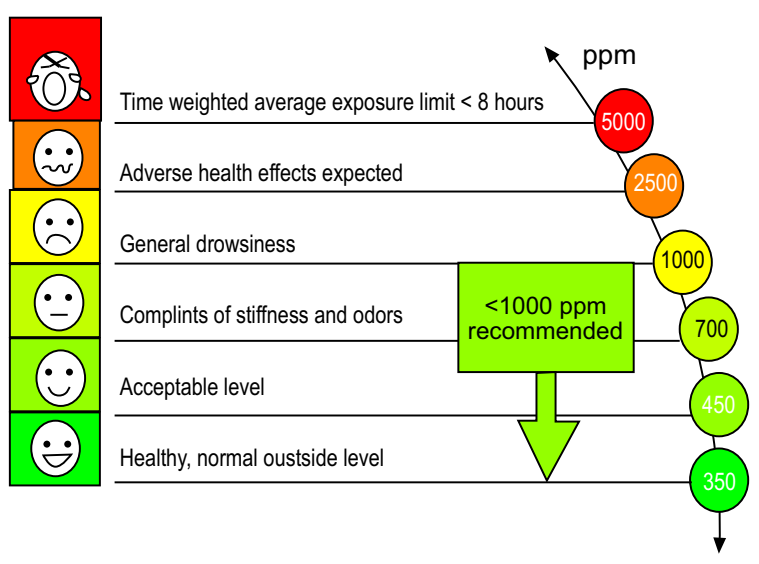

Fig. 3. $\mathrm{CO}_{2}$ Levels related to different human health conditions.

Table 2. Temperature/humidity ranges for comfort

\begin{tabular}{|c|c|c|}
\hline Conditions & Relative humidity & $\begin{array}{l}\text { Acceptable } \\
\text { operating } \\
\text { temperature }\end{array}$ \\
\hline \multirow[t]{2}{*}{ Light clothing in summer } & If 30 percent then & 24.5 to $28^{\circ} \mathrm{C}$ \\
\hline & If 60 percent then & 23 to $25.5^{\circ} \mathrm{C}$ \\
\hline \multirow[t]{2}{*}{ Warm clothing in winter } & If 30 percent then & 20.5 to $25.5^{\circ} \mathrm{C}$ \\
\hline & If 60 percent then & 20 to $24{ }^{\circ} \mathrm{C}$ \\
\hline
\end{tabular}


From Table 2 (ASHRAE-55, 2010) acceptable temperatures have been assumed for Table 2 as per human comfort indoors after providing HVAC cooling system.

From the above Fig. 4 (WHO, 2019) it has been assumed that $40 \mathrm{~L}=10.57$ US Gallons of water is required per person/day $40 \mathrm{~L}$ water per person/day covers the water requirements for survival (preparation of food and drinking), elementary hygiene practices, normal cooking needs, personal washing and washing clothes.

From Fig. 5 (Michael, 2016) different size HVAC systems are assumed for different floors of the building having retail shops on ground floor, 4 Offices on $1^{\text {st }}$ floor, Gym, hall and pray area on $2^{\text {nd }}$ floor and from $3^{\text {rd }}$ floor till $12^{\text {th }}$ floor there are four residential apartments on each floor. So, for an apartment having a size of

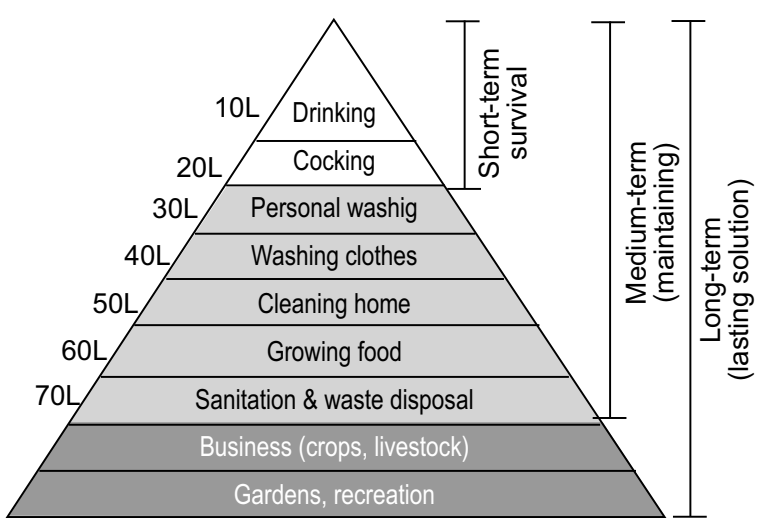

Fig. 4. Hierarchy of water requirements.

\begin{tabular}{|c|c|c|c|c|c|}
\hline & & HVAC SY & TEM SIZI & NG & \\
\hline & Blue & Green & Yellow & Orange & Red \\
\hline Coolir & & & & & \\
\hline 1.5 Tons & $700-100 \mathrm{sf}$ & $700-1050 \mathrm{sf}$ & $600-1000 \mathrm{sf}$ & $600-950 \mathrm{sf}$ & $600-900$ sf \\
\hline 2 Tons & 1101-1400sf & 1151-1350sf & 1001-1300sf & 951-1250sf & $901-1200 \mathrm{sf}$ \\
\hline 2.5 Tons & 1401-1650sf & 1351-1600sf & 1301-1600sf & 1251-1550sf & 1201-1500sf \\
\hline 3 Tons & 1651-2100sf & 1601-2000sf & 1601-1900sf & 1501-1850sf & 1501-1800sf \\
\hline 3.5 Tons & 2101-2300sf & 2001-2250sf & 1901-2200sf & 1851-2150sf & 1801-2100sf \\
\hline 4 Tons & 2301-2700sf & 2251-2700sf & 2201-2600sf & 2151-2500sf & 2101-2400sf \\
\hline 5 Tons & 2701-3300sf & 2751-3300sf & 2601-3200sf & 2501-3100sf & 2401-3000sf \\
\hline & & & & & \\
\hline & 40-60 BTU/sf & 35-50 BTU/sf & 30-45 BTU/s & f $20-40$ BTU & $15-35 \mathrm{BTU} / \mathrm{sf}$ \\
\hline
\end{tabular}

Fig. 5. HVAC system according to size.
300 sq. yards $=2700$ sq. ft. (proposed designed area) 4 tonnes HVAC system is assumed from Fig. 5.

The questionnaire designed comprised of two sections: in first section respondents were asked about their demographics which included gender, age and experience of working in their respective fields. The other part of the questionnaire comprising questions which were asked from respondents as to know about their awareness regarding green buildings, green building technologies, green building codes and regulations and particularly awareness regarding ISO 14001 environmental management system. The questions were designed after conducting a detailed literature review.

Stratified sampling technique was used in which construction industry professionals were focussed including civil engineers, contractors/ builders, architects/ structure design engineer and consultants working on different projects in Karachi. The process of data collection accomplished by conducting a pilot survey in which professional working on different construction projects in Pakistan particularly Karachi were asked to answer questions. Professionals working in type of firms contractor/builders, architects/structure design engineer and consultants were requested to fill a questionnaire to know about their point of view on green buildings and its practices.

Standard deviation. It is a number which shows how measurements for a group are elongated from the average (mean) value. A low standard deviation means that most of the numbers are nearest to the mean. A high standard deviation means that the numbers are elongated (Walker, 1929).

$$
\mathrm{SD}=\sqrt{ }(\mathrm{x}-\text { mean })^{2}
$$

Relative importance index (RII). It is a tool used for ranking parameters. The RII of each parameter is calculated and the parameters are ranked based on the RII of each parameter (Mamata et al., 2016).

$$
\mathrm{RII}=\Sigma \mathrm{W} /(\mathrm{N} \times \mathrm{A})
$$

where:

$\mathrm{W}$ is the weighting given by respondents to each factor from 1 to $5, \mathrm{~A}$ is the highest weight which is 5 , and $\mathrm{N}$ is the total number of respondents which is 60 .

The chi-square test is computationally simple. It is used to examine independence of two definite variables or to assess how well a sample fits the distribution of an 
already recognized population (goodness of fit) (Franke et al., 2011).

Formula to calculate Chi-Square Value is:

$$
\mathrm{X}^{2}=\Sigma\left[(\mathrm{O}-\mathrm{E})^{2} / \mathrm{E}\right]
$$

where:

$\mathrm{O}=$ observed value and $\mathrm{E}=$ expected value.

Research design/methodology. Research objectives. To investigate and study impact of local construction projects with the specific end goal to decide whether they are using green building practices, to study impact of green building techniques used in the construction of buildings and to review energy efficient and environmental friendly features to be used in the planning and design of an energy efficient and environmentally friendly building for Karachi.

Hypothesis. There is a sufficient gap of data on awareness/knowledge on energy-efficient and environmentally friendly building.

Ho: There is a lack of awareness/ knowledge on energy efficient plus environmental friendly buildings.

H1: There is much awareness/ knowledge on energy efficient \& environmental friendly buildings.

Qualitative design (survey). We propose a qualitative study having a population size of 10,000 (assumed) having a confidence level of $95 \%$ and margin of error $10 \%$. Therefore, sample size of sixty was selected in which most people were construction industry professionals to check out the awareness regarding green buildings and its related techniques and also to give them some awareness.

Data collection. Data collection procedure comprised of two parts:

An online questionnaire survey to gather information regarding the effects on the natural environment because of construction activities and to test awareness regarding the green buildings and its practices in local construction market of Pakistan, conducting personal interviews and a focus group having four construction industry and professionals associated with mega infrastructure projects in Karachi.

Data processing tools. The collected data is processed using MS-Excel for mean, standard deviation (SD) and relative importance index RII calculations. Ranking of parameter is been done as per RII. Moreover, Chisquare test is performed to test the Null hypothesis.

\section{Results and Discussion}

As a result of questionnaire survey and analysis we propose the following:

Results of green building awareness survey in Karachi. The results from the above Fig. 6 confirm that respondents do believe that living in traditional residential buildings may expose us to harmful effects of secondary emissions produced by reaction of ozone with building materials.

In Fig. 7 according to survey results the respondents are very much inclined towards living in sustainable buildings but for that they need to have knowledge regarding some essential green building materials to attain energy efficiency and environmental sustainability.

Qualitative data analyzed using Chi-Squared test. From the above Fig. 8 it has been revealed that majority of the respondents are not aware regarding the green

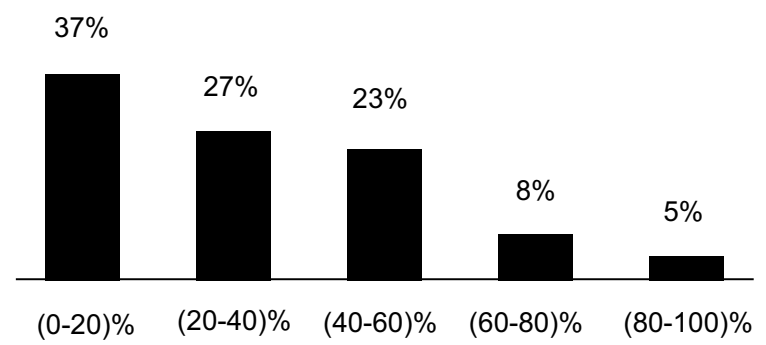

Fig. 6. Ozone exposure living in residential buildings.

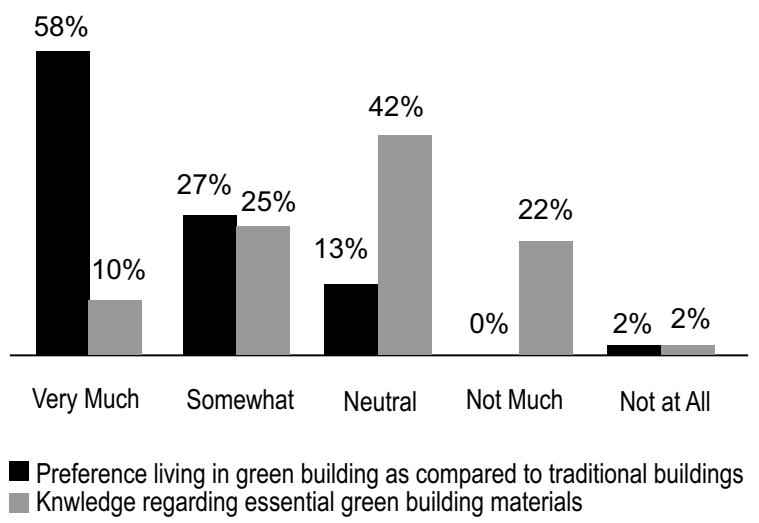

Fig. 7. Essential green building materials for sustainable living. 
buildings. Now applying Chi-Square Test to calculate the Chi-Square value and to test the null hypothesis i.e. there is lack of awareness/ knowledge regarding green buildings in Pakistan's local construction market.

Based on our chi-square test result we conclude that our null hypothesis is accepted and therefore we can conclude that there is lack of awareness/ knowledge on energy efficient plus environmental friendly buildings as per the conducted survey.

From Fig. 9 green buildings are a desirable investment to the investors and purchasers therefore, they are preferred more by the investors and purchasers as compared to traditional buildings.

Construction activities always create an impact on the natural environment. Waste and building materials produced due to excavation and demolition work on construction sites has always led to a serious environmental concern. In Fig. 10 to overcome the serious issue ISO 14001 Environment Management System can be

Table 3. Observed and expected values form survey for Chi square test

\begin{tabular}{llllll}
\hline \hline & $\begin{array}{l}\text { Very } \\
\text { much }\end{array}$ & Somewhat & Neutral & Not much & $\begin{array}{l}\text { Not } \\
\text { at all }\end{array}$ \\
\hline $\begin{array}{l}\text { Observed } \\
\text { values (O) }\end{array}$ & 2 & 16 & 15 & 16 & 11 \\
$\begin{array}{l}\text { Expected } \\
\text { values (E) }\end{array}$ & 12 & 12 & 12 & 12 & 12 \\
\hline \hline
\end{tabular}

Sample size $=60 ;$ Alpha $=$ level of significance $=0.01$ (assumed); Degrees of freedom $=\mathrm{df}=4$ (Always $1<$ possible outcomes); $\mathrm{X}^{2}=11.835$ (Chi-square value); Critical value $=$ $\mathrm{CV}=13.277$ (from Chi-square table); $\mathrm{X}^{2}<$ Critical value, it proves we accept Null Hypothesis 'Ho'.

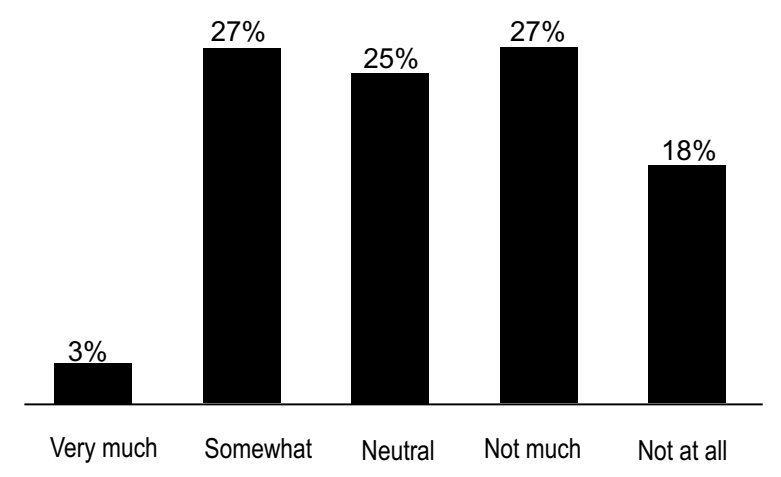

Fig. 8. Results showing awareness regarding green buildings among respondents. adopted which according to the survey has considerably lesser awareness among respondents. ISO 14001 EMS framework can be used by construction stakeholders for effective waste minimization from construction sites.

In Fig. 11 the results of the questionnaire survey show that respondents do believe that green buildings can provide smart growth and sustainable development. Non green buildings create an impact on the environment of inhabitants so for future practice construction stakeholders should adopt green buildings for a sustainable and healthy environment.

In the above Fig. 12 it has been revealed that 52\% respondents are well aware of the regulation LEED (Leadership in Energy and Environmental Design), $17 \%$ respondents have knowledge about Evaluation Standard for Green Building (ESCB), 12\% respondents know about Green Star. Whereas, 33\% respondents revealed that they are not aware about the Green construction regulations.

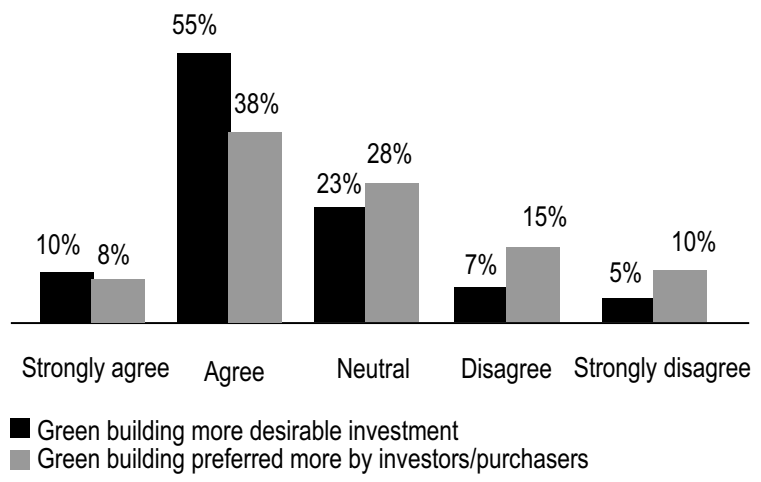

Fig. 9. Impact of green buildings from investors/ purchasers point of view.

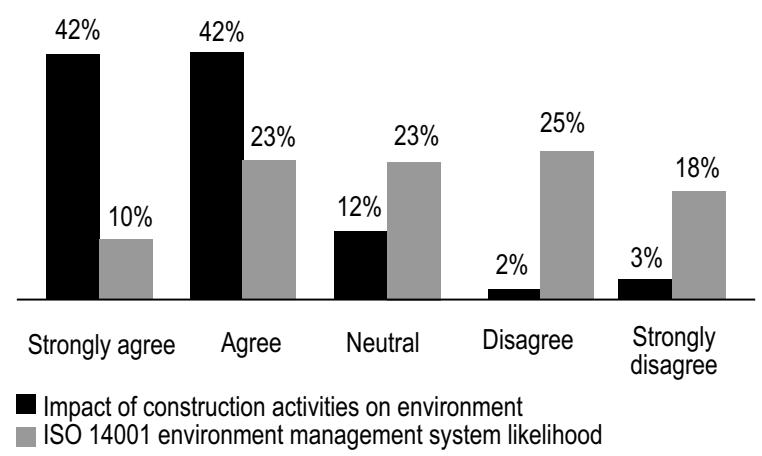

Fig. 10. Awareness regarding ISO 14001 environment management system. 
The survey analysed responses on Green practices based on the following types:

Educational Institutes, Residential Buildings, Commercial and Public Buildings, Laboratories and Healthcare Facilities.

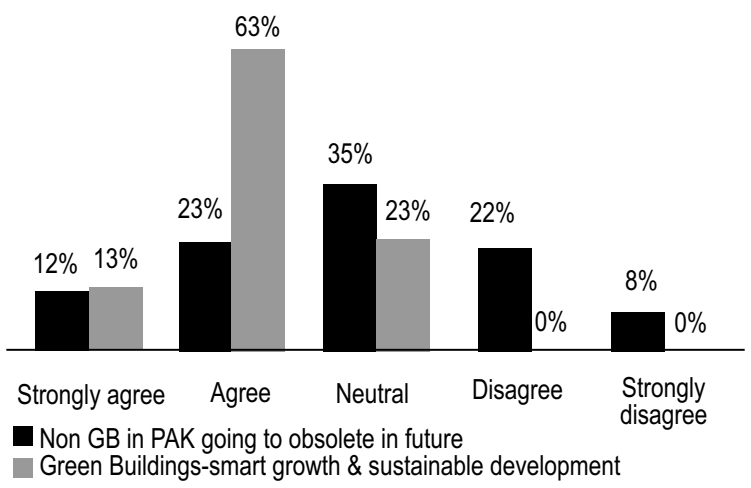

Fig. 11. Future of green buildings for smart growth \& sustainable development.

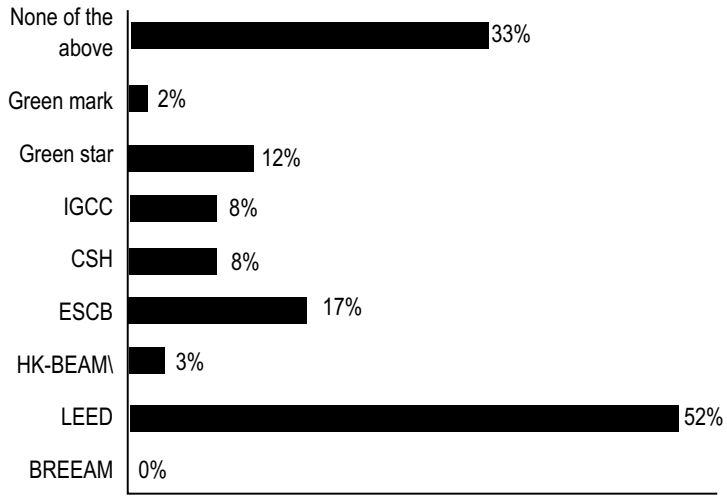

Fig. 12. Results showing awareness regarding green construction regulations.

Table 4. Awareness regarding green construction regulations

\begin{tabular}{lllll}
\hline \hline & Mean & SD & RII & Rank \\
\hline BREEAM & 0.00 & 0.00 & 0.00 & 9 \\
LEED & 0.52 & 0.50 & 0.114 & 2 \\
HK-BEAM & 0.03 & 0.18 & 0.011 & 8 \\
ESCB & 0.17 & 0.38 & 0.074 & 4 \\
CSH & 0.08 & 0.28 & 0.046 & 6 \\
IGCC & 0.08 & 0.28 & 0.055 & 5 \\
GREEN STAR & 0.12 & 0.32 & 0.090 & 3 \\
GREEN MARK & 0.02 & 0.13 & 0.014 & 7 \\
None of the above & 0.34 & 0.48 & 0.333 & 1 \\
\hline \hline
\end{tabular}

As per the results as shown in Fig. 13 commercial and public buildings should be incorporating Green practices into its construction as demonstrated by $43 \%$ responses. $35 \%$ responses were in favour of residential buildings whereas $32 \%$ respondents believe that all educational institutes, residential buildings, commercial and public buildings, laboratories and healthcare facilities should incorporate green practices into its construction.

Ranking of green practices into construction is preferably done in commercial and public buildings as compared to hospitals and residential buildings which have crucial requirements of safety so it does not require strict implementation of green practices into its construction.

From Table 5 the calculated percentages the mean, standard deviation and rank were also calculated.

From the above Fig. 14 it has been revealed that Environmental stability is the most important aspect of Green Construction. 63\% of responses were found in favour of Environmental Stability. Energy and water efficiency is considered as second major aspect of Green construction with around $30 \%$ of responses. From the

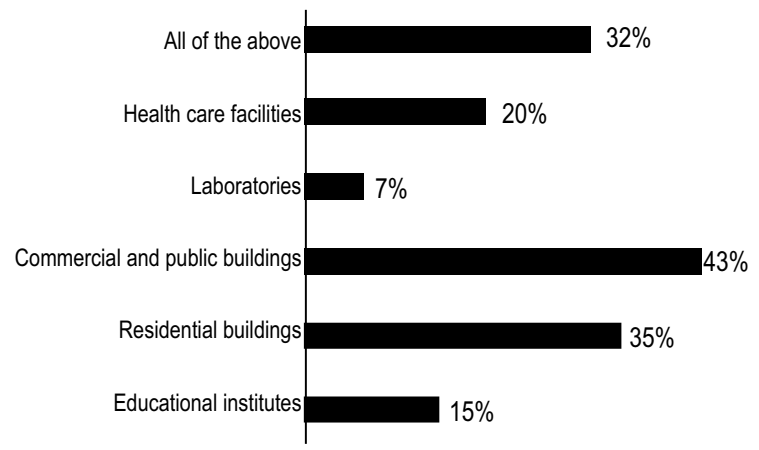

Fig. 13. Results showing building type to incorporate green practices into its construction.

Table 5. Building type incorporating green practices into its construction

\begin{tabular}{lllll}
\hline \hline & Mean & SD & RII & Rank \\
\hline Educational institutes & 0.07 & 0.25 & 0.011 & 5 \\
Residential buildings & 0.2 & 0.40 & 0.066 & 3 \\
$\begin{array}{l}\text { Commercial and public } \\
\text { buildings }\end{array}$ & 0.23 & 0.43 & 0.116 & 2 \\
Laboratories & 0.02 & 0.13 & 0.011 & 5 \\
Healthcare facilities & 0.05 & 0.22 & 0.041 & 4 \\
All of the above & 0.43 & 0.50 & 0.433 & 1 \\
\hline \hline
\end{tabular}


calculated percentages the mean, standard deviation and rank of different aspects were found.

Environmental stability has been found to be one of the major aspects of green construction along with energy/ water efficiency, as validated in the data provided in Table 6.

In Fig. 15 according to the survey results the reason behind lack of knowledge in construction methods is rated high is that there is lack of research work and detailed studies done in Pakistan on benefits of green construction due to which the construction stakeholders are unaware about Green sustainable development. Also, the reason why market factors and lack of owner interests stands low is that cost of constructing Green structures is very high which is a noteworthy worry that makes it hard to persuade stakeholders to embrace green structures.

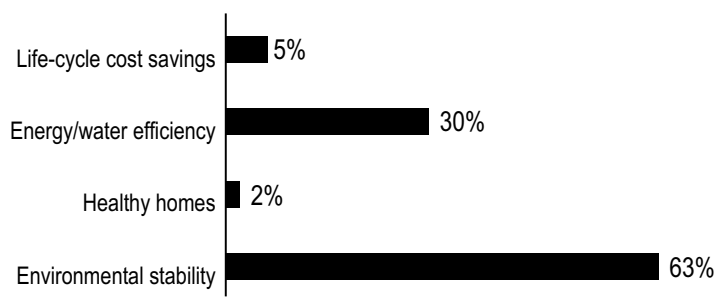

Fig. 14. Result showing major aspects of green building construction.

Table 6. Ranking of major aspects of green building

\begin{tabular}{lllll}
\hline \hline Measure & Mean & SD & RII & Rank \\
\hline Environmental stability & 0.63 & 0.49 & 0.158 & 2 \\
Energy/water efficiency & 0.30 & 0.46 & 0.225 & 1 \\
Life-cycle cost savings & 0.05 & 0.22 & 0.05 & 3 \\
Healthy homes & 0.02 & 0.13 & 0.008 & 4 \\
\hline \hline
\end{tabular}

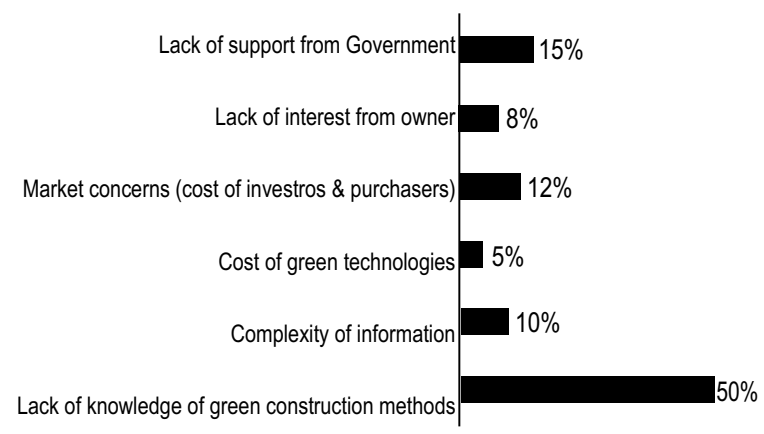

Fig. 15. Results showing major obstacle in green construction.
Lack of knowledge of green construction methods has been found as one of the major obstacle in green construction which is because the construction industry professionals are unaware it is validated in the data provided in Table 7.

From the calculated percentages the mean, standard deviation, RII and rank were also calculated.

The results of questionnaire survey as shown in Fig. 16 show that around $30 \%$ of the respondents believe that energy conservation and environmental/resource conservation are the major driving factors for green building development. This is because Pakistan is facing serious energy crisis and also change in climate conditions which is causing global warming so respondents tend to believe that energy and environmental efficiency is must.

Also, $15 \%$ of respondents believe that improving indoor environmental quality are the major driving factors for green sustainable development because respondents want occupant friendly homes and cost effective as well for investors as well as purchasers.

Table 7. Ranking of obstacles in green construction

\begin{tabular}{|c|c|c|c|c|}
\hline & Mean & SD & RII & Rank \\
\hline $\begin{array}{l}\text { Lack of knowledge of green } \\
\text { construction methods }\end{array}$ & 0.50 & 0.50 & 0.083 & 2 \\
\hline Complexity of information & 0.10 & 0.30 & 0.033 & 5 \\
\hline Cost of green technologies & 0.05 & 0.22 & 0.025 & 6 \\
\hline $\begin{array}{l}\text { Market concerns (cost of } \\
\text { investors \& purchasers) }\end{array}$ & 0.12 & 0.32 & 0.077 & 3 \\
\hline Lack of interest from owner & 0.08 & 0.28 & 0.069 & 4 \\
\hline $\begin{array}{l}\text { Lack of support from } \\
\text { government }\end{array}$ & 0.15 & 0.36 & 0.15 & 1 \\
\hline
\end{tabular}

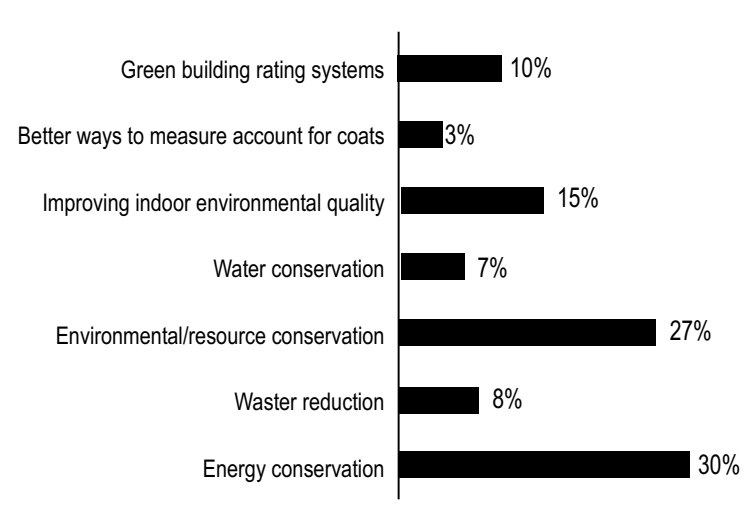

Fig. 16. Results showing major driving factor to acquire for sustainable development. 
From the calculated percentages the mean, standard deviation and rank were also calculated.

From the above Table 8 taking the top driving factors for green and sustainable development into consideration i.e. environmental/ resource conservation, improving indoor environmental quality and energy and water conservation an energy-efficient and environmental friendly building is proposed in the following section.

Table 8. Ranking of drivers for sustainable development

\begin{tabular}{lllll}
\hline \hline & Mean & SD & RII & Rank \\
\hline Energy conservation & 0.30 & 0.46 & 0.042 & 4 \\
Waste reduction & 0.08 & 0.28 & 0.023 & 7 \\
$\begin{array}{l}\text { Environmental/resource } \\
\text { conservation }\end{array}$ & 0.27 & 0.45 & 0.114 & 1 \\
$\begin{array}{l}\text { Water conservation } \\
\begin{array}{l}\text { Improving indoor } \\
\text { environmental quality }\end{array}\end{array}$ & 0.07 & 0.25 & 0.038 & 5 \\
$\begin{array}{l}\text { Better ways to measure } \\
\text { account for costs }\end{array}$ & 0.03 & 0.18 & 0.028 & 6 \\
$\begin{array}{l}\text { Green building rating } \\
\text { systems }\end{array}$ & 0.10 & 0.30 & 0.10 & 3 \\
\hline \hline
\end{tabular}

\section{Conclusion}

It is concluded that there is lack of knowledge regarding energy-efficient and environmental friendly buildings in Karachi's construction market and designers and builders are not aware about essential green building materials.

There is a serious need for creating awareness regarding ISO 14001 Environmental Management System among construction stakeholders in order to reduce construction wastes on site. Also, construction stakeholders must be informed regarding the Green building codes and standards used around the world which include LEED, BREEAM, HK-BEAM, ESGB, CSH, IGCC, BCA GREEN MARK and GREEN STAR. In addition, the construction stakeholders should adopt Building codes of Pakistan-Energy Provisions for energy-efficient design and construction.

According to the results we found that environmental/ resource conservation, improving indoor environmental quality and energy conservation are major driving factors for green building construction. Also, we found that lack of knowledge regarding green construction methods and lack of support from the Government are major barriers towards green construction.
This paper is a first attempt to apply green practices to building construction. As per the results, the important benefits from green construction are environmental stability and energy/water efficiency. For future work taking these benefits into consideration a prototype of a residential cum commercial building would be proposed and will be presented for the metropolis incorporating energy efficient and environmental friendly features like green roof, insulation in walls and windows, tree plantation in outer area of the building and balcony, use of solar panels and LED lights, Variable Voltage Variable Frequency (VVVF) elevators and wastewater treatment plant and will further be recommended to the construction stakeholders which will help in moving towards green construction. It is concluded that if construction of a building takes place taking into consideration the impacts of operational phase than a performance based building can be constructed, which will not only save energy but also our economy. Regulatory authorities like Karachi Development Authority (KDA), Defense Housing Authority (DHA) are suggested to formulate regulations and codes for green building codes so that sustainability could be incorporated in local construction sector. The National Energy Conservation Center (ENERCON) in collaboration with Pakistan Engineering Council (PEC) is also suggested to implement Building Energy Code of Pakistan Energy Provision 2011 in new structures for energy savings.

Conflict of Interest. The authors declare no conflict of interest.

\section{References}

Aashish, S., Abishey, S., Muneesa, S., Venu, S., Varun. 2011. Life cycle assessment of buildings: a review. Renewable and Sustainable Energy Reviews, 15: 871-875.

Abas, N., Kalair, A., Khan, N., Kalair, A.R. 2017. Review of GHG emissions in Pakistan compared to SAARC countries. Renewable and Sustainable Energy Reviews, 80: 990-1016.

Ahn, Y.H., Pearce, A.R., Wang, Y., Wang, G. 2013. Drivers and barriers of sustainable design and construction: The perception of green building experience. International Journal of Sustainable Building Technology and Urban Development, 4: 35-45.

Amos, D., Albert, P.C.C. 2016. Review of barriers to green building adoption. Sustainable Development, 25: $167-179$. 
Amos, D., Zhang, C., Chan, A.P.C. 2017. Drivers for green building: a review of empirical studies. Habitat International, 60: 34-49.

Arif, S. 2011. Environmental issues and energy conservation in buildings in Pakistan: role of architectural intervention. The Nucleus, 48: 137142.

ASHRAE-55. 2019. Canadian centre for occupational health and safety - adapted from ASHRAE 552010. [online]. available: http://www.ohsrep.org.au/ hazards/call-centres/offices-temperature-andhumidity-what-are-the-rules. [Accessed: 25 March, 2019].

Berndtsson, J.C., Bongtsson, L., Jinno, K. 2009. Runoff water quality from intensive and extensive vegetated roofs. Ecological Engineering, 35: 369-380.

Castleton, H.F., Stovin, V., Beck, S.B.M., Davison, J.B. 2010. Green roofs; building energy savings and the potential for retrofit. Energy and Buildings, 42: 1582-1591.

Chi, P., Hoang, Kerry, A.K., Richard, L.C. 2009. Ozone removal by green building materials. Building and Environment, 44: 1627-1633.

Clevenger, C.M., Haymaker, J. 2006. The impact of the building occupant on energy modeling simulations. pp. 1-10 [Online] available: https://pdfs. semanticscholar.org/8442/dab9703f2e20be1 fe27 288d3962b6052d419.pdf?_ga=2.15487474.5779 3859.1582559727-125611744.1572781114. [Accessed: March 24, 2019].

$\mathrm{CO}_{2}$ Monitor. 2019. A layman's' explanation of $\mathrm{CO}_{2}$ Levels \& Monitoring Explained, Research \& Markets[online]. available: https://www.co2monitor. com.au/.[accessed: 25 March, 2019].

Darko, A., Chan, A.P.C., DerGratt, O.M., Amyeaoo, E.E. 2017. Drivers for implementing green building technologies: an international survey of experts. Journal of Cleaner Production, 145: 386-394.

Doug, B., Missios, P., Doshi, H., Li, T.Y. 2005. Report on the environmental benefits and costs of green roof technology for the City of Toronto. Prepared for city of Toronto and Ontario centres of excellence. Earth and Environmental Technologies, 63 p.

Franke, T.M., Timothy, H.O., Christie, C.A. 2011. The Chi-Square test: often used and more often misinterpreted. American Journal of Evaluation, 33: 448458.

Imbabi, M.S., Collette, C. 2012. Trends and developments in green cement and concrete technology. International Journal of Sustainable Built
Environment, 1: 194-216.

ISO 14001, 2015. "A layman's' explanation of "Introduction to ISO 14001Switzerland: 2015", 2015. [Online]. available: https://www.iso.org/iso/ introduction_to_iso_14001.pdf. [accessed: March 24, 2019].

Koehler, M. 2003. Plant survival research and biodiversity: lessons from Europe. In: The First Annual Greening Rooftops for Sustainable Communities Conference, pp. 313-322, Awards and trade show, Chicago.

Mamata, R., Chauhan, P., Patel, D., Fanchal, C., Bravsar, D. 2016. RII \& IMPI: Effective techniques for finding delay in construction project. International Research Journal of Engineering and Technology, 3: 1173-1177.

Mentens, J., Raes, D., Hermy, M. 2006. Green roofs as a tool for solving the rainwater runoff problem in the urbanized 21st century. Landscape and Urban Planning, 77: 217-226.

Michael, B. 2016. HVAC sizing [online]. Last update: February 2016 Available: http://michaelbluejay.com/ electricity/hvac-sizing.html. [accessed: 25 March, 2019].

Mueller, F.X. 1973. Decomposition rates of ozone in living areas. Environmental Science and Technology, 7: 342-346.

OECD. 2012. OECD Environmental Outlook. 350 p. UN Educational Scientific and Organization, Publishing. Available: http://dx.doi.org/10.1787/ 9789264122246-en

Sohail, M., Qureshi, M.U.D. 2011. Energy-efficient buildings in Pakistan. Science Vision, 16-17: 27 38.

Stephanie, V. 2019. Green building standards and certification systems. Available: https://www.wbdg. org/resources/green-building-standards-andcertification-systems

Stovin, V. 2007. Green roofs-getting sustainable drainage off the ground. In: $\sigma^{\text {th }}$ International Conference of Sustainable Techniques and Strategies in Urban Water Mangement, pp. 11-18, Novatech 2007, Lyon, France.

Strahinja, S. 2019. "ISO 14001 Case Study: Waste Management in a Construction Company" https:// advisera.com/14001academy/blog/2017/02/27/iso14001 -case-study-waste-management-in-aconstruction-company/ Feb 27, 2017. [Accessed: March 24, 2019]

Teemusk, A., Mander, U. 2009. Green roof potential to 
reduce temperature fluctuations of a roof membrane: a case study from Estonia. Building and Environment, 44: 643-650.

Thomas, A. 2017. Sustainable Mass Transit. Chapter 4, pp. 45-59, Environmental Impacts, New York, USA.

United Nations. 2017. Department of economic and social affairs, Population Division. 2017. Household Size and Composition around the World 2017-Data Booklet.

Walker, H.M. 1931. Studies in the History of the Statistical Method, pp. 24-25, Baltimore, MD: Williams \& Wilkins, Columbia.

WEF, 2016. Environmental Sustainability Principles for the Real Estate Industry. World Economic Forum Industry Agenda Council on the Future of Real Estate and Urbanization. Available: http://www3. weforum.org/docs/GAC16/CRE_Sustainability.pdf
Weschler, C.J. 2000. Ozone in indoor environments: concentration and chemistry. International Journal of Indoor Air, 10: 269-288.

WHO. 2019. Technical notes on drinking-water, sanitation and hygiene in emergencies, WEDC UK available: http://www.who.int/water_sanitation_ health/publications/2011/tn9_how_much_water_ en.pdf. [Accessed: 25 March, 2019].

World Resources Institute (WRI). 2007. Earth Trends: Environmental Information. [online], available: http://earthtrends.wri.org. Washington DC, USA.

Yang, J., Qian, Y.U., Gring, P. 2008. Quantifying air pollution removal by green roofs in Chicago. Atmospheric Environment, 42: 7266-7273.

Zhang, Y., Wang, J., Hu, F., Wang, Y. 2017. Comparison of evaluation standards for green building in China, Britain, United States. Renewable and Sustainable Energy Reviews, 68: 262-271. 